\title{
Penerapan Teknologi Proses Produksi Untuk Meningkatkan Kapasitas Dan Kualitas Kecap Manis UKM Bumi Makmur Sejahtera
}

\author{
Gusti Fauza $^{1 *}$, Heru Sukanto ${ }^{2}$, Catur Sugiarto ${ }^{3}$, Syamsul Hadi ${ }^{2}$, Okid Parama Astirin ${ }^{4}$, \\ Wisnu Nurcahyo ${ }^{5}$, Ari Prasetyo ${ }^{2}$ \\ ${ }^{1}$ Program Studi Ilmu Teknologi Pangan, Fakultas Pertanian Universitas Sebelas Maret \\ ${ }^{2}$ Program Studi Teknik Mesin, Fakultas Teknik Universitas Sebelas Maret \\ ${ }^{3}$ Program Manajemen, Fakultas Ekonomi dan Bisinis Universitas Sebelas Maret \\ ${ }^{4}$ Program Studi Biologi, Fakultas Matematika dan Ilmu Pengetahuan Alam Universitas Sebelas Maret \\ ${ }^{5}$ Departemen Parasitologi, Fakultas Kedokteran Hewan, Universitas Gadjah Mada \\ *gustifauza@staff.uns.ac.id
}

\begin{abstract}
Abstrak
Kegiatan pengabdian masyarakat ini bertujuan untuk meningkatkan tidak hanya kapasitas namun juga kualitas produk kecap manis kecap manis Bumi Makmur Sejahtera (BMS) khas Wonogori yang terdapat di Desa Bulusari, Kecamatan Bulusulur, Wonogiri Jawa Tengah. Dari observasi lapangan ditemukan beberapa permasalahan, yaitu waktu siklus produksi per batch produk yang masih tinggi dan proses produksi yang tidak efisien. Hal ini berdampak terhadap terbatasnya kapasitas produksi UKM. Beberapa proses yang memakan waktu lama adalah proses pemasakan (9 jam) dan pengemasan (12 jam). Permasalahan berikutnya terkait mutu dan keamanan pangan dimana wajan pemasakan yang bersentuhan langsung dengan produk terbuat dari semen (bahan yang bisa mengelupas). Kondisi ini tidak sesuai dengan konsep cara produksi pangan yang baik (CPPB) untuk industri rumah tangga. Oleh sebab pada kegiatan pengabdian ini akan diaplikasikan teknologi proses produksi yang tidak hanya meningkatkan kapasitas namun juga kualitas dan keamanan produk. Tahapan kegiatan yang dilakukan adalah: a) inisiasi dan sosialisasi program, b) pelaksanaan program, c) monitoring dan evaluasi program. Aplikasi teknologi yang diusulkan adalah sebuah Introduksi lini produksi dengan system pengadukan otomatis dan pengemasan yag lebih efisien. Penerapan teknologi ini diharapkan dapat meningkatkan kapasitas dan kualitas produk kecap. Kemudian penggunaan bahan untuk alat yang terbuat dari stainless steel, merupakan salah satu solusi untuk menurunkan cemaran fisik. Dengan lini produksi baru ini, waktu produksi lebih pendek sehingga kapasitas meningkat signifikan. Disamping itu kualitas akan lebih baik karena dengan pengadukan otomatis adonan akan lebih homogen, serta keamanan pangan juga akan meningkat karena peralatan terbuat dari bahan yang aman untuk pengolahan produk pangan.
\end{abstract}

Kata kunci—teknologi proses, kecap manis, CPPB, kapasitas, kualitas

\section{Pendahuluan}

Menurut Standar Industri Indonesia (SII No. 32 tahun 1974), kecap adalah adalah cairan kental yang mengandung protein yang diperoleh dari rebusan kedelai yang telah diragikan dan ditambahkan gula, garam serta rempah rempah. Di Indonesia digunakan sebagai bahan penyedap makanan dalam berbagai masakan dimana syarat mutunya adalah: kadar protein mutu I minimal 6 persen dan mutu II minimal 2 persen; Kadar logam-logam berbahaya negatif dan kadar bau, rasa, dan lain-lain adalah normal. Menurut Septiani (2011), selain rasa dan konsistensi aroma, kekentalan merupakan alasan utama konsumen membeli produk kecap, diikuti berikutnya oleh faktor harga dan kemasan.

Riset yang dilakukan Maryani (2007) menunjukkan, fenomena industri kecap di Indonesia yang cukup menarik, dimana permintaan kecap di Indonesia meningkat setiap tahunnya. Pada tahun 2015, di Indonesia terdapat 94 unit 
usaha industri kecap dengan nilai produksi 7.1 triliun dan serapan tenaga kerja sebesar 8500 orang. Namun untuk memenuhi tingginya kebutuhan masyarakat itu, Indonesia masih mengimpor, yang nilainya tiap tahun mengalami peningkatan. Hal ini tentunya menjadikan bisnis kecap manis merupakan pasar yang masih potensial untuk dikembangkan.

Jika dilihat dari perspektif rantai pasok, bisnis industri kecap tidak hanya menghidupi pelaku bisnis di industri ini saja. Pelaku bisnis lain seperti industri gula (downstream) yang merupakan bahan baku utama kecap, juga bergantung hidupnya terhadap perkembangan bisnis kecap ini. Begitu juga bisnis kuliner (upstream), yang membutuhkan kecap dengan kualitas baik. Dengan kata lain, peningkatan performa industri kecap baik itu secara kuantitas maupun kualitas akan memberikan impact atau dampak terhadap bisnis di bagian downstream dan upstream-nya.

Di Wonogiri, belum terlalu banyak pebisnis yang bergerak di industri ini. Sementara permintaan kecap dengan khas rasa Wonogiri cukup tinggi. Hal inilah yang menginisiasi Wikky Sasana Murti mendirikan usaha kecil menengah Bumi Makmur Sejahtera (BMS) pada tahun 2019. Terletak di Desa Bulusari RT III RW III Bulusulur, Wonogiri, Jawa Tengah, usaha dagang ini memproduksi kecap manis dengan merek dagang BMS. UKM memiliki karyawan sebanyak 6 orang (termasuk pemilik) dan memproduksi kecap secara rutin setiap bulannya. Berdirinya bisnis kecap ini tentu juga membuka peluang kelompok UKM lainnya yang memperoduksi bahan baku utama, yaitu gula tebu dan gula aren. Eksistensi produk kecap BMS ini menjadi magnet untuk perkembangan kelompok bisnis lainnya. Oleh sebab itu upaya perbaikan proses pengolahan untuk meningkatkan kapasitas maupun kualitas nya penting untuk dilakukan karena akan memberikan dampak social dan ekonomi yang besar bagi masyarakat yang berkecimpung di usaha ini.

UKM-BMS, memiliki visi yaitu menjadi perusahaan yang memproduksi kecap yang sehat, enak, dan berkualitas bagi konsumen. Sedangkan misinya yaitu dapat memperluas pangsa pasarnya sampai ke luar kota, serta meningkatkan target produksi meningkat menjadi 3 ton per bulan. Pasar produk ini sangat prospektif, karena selain belum ada produsen kecap mais khas Wonogiri, permintaan terhadap produk ini relatif tinggi. Hal ini dibuktikan dengan adanya kontinuitas permintaan terhadap produk ini, meskipun baru dipasarkan di wilayah sekitar Wonogiri. Distribusi produk masih difokuskan kepada warung-warung di wilayah Wonogiri. Keterbatasan kapasitas produksi menghambat UKM ini untuk dapat menjangkau pasar yang lebih luas.

Berdasarkan diskusi intens yang dilakukan dengan mitra, teridentifikasi beberapa permasalahan yang dihadapi oleh mitra yaitu, kapasitas produksi yang masih terbatas dan konsistensi mutu dan keamanan produk kecap. Saat ini kapasitas produksi kecap masih sekitar 1 ton per bulan yang menghasilkan 22.000 sachet dan 35.000 botol kecap manis. Dari hasil pengamatan terdapat dua aktivitas yang waktu prosesnya cukup lama, yaitu pemasakan (9 jam) dan pengemasan (6-8 jam untuk satu batch produksi yang setara dengan $300 \mathrm{~kg}$ ). Aktivitas pemasakan harus dibarengi dengan pengadukan/penapisan, agar adonan tidak tumpah keluar dari wajan pemasakan. Aktivitas penapisan dilakukan untuk memecah buih-buih yang terbentuk selama proses pemasakan, yang jika tidak dipecah akan menyebabkan rebusan adonan kecap meluber sampai keluar wajan. Proses ini memakan waktu yang cukup lama dan karena dilakukan secara manual, sumber daya yang digunakan menjadi tidak efisien.

Dalam hal mutu produk, dua permasalahan dihadapi oleh pemilik UKM, konsistensi kekentalan kecap dan potensi cemaran fisik. Dalam sesi diskusi dan brainstorming, pemilik mengemukakan bahwa kekentalan kecap antar kemasan itu tidak sama. Pengujian secara random menunjukan terdapat variasi nilai kekentalan meskipun produk berasal dari batch produksi yang sama. Dugaan sementara, hal ini terkait dengan permasalahan homogenitas adonan saat proses pemasakan dan setelah pemasakan. Permasalahan berikutnya terkait keamanan produk pangan terhadap potensi cemaran fisik. Saat ini wajan pemasakan yang digunakan berbahan dasar semen yang berpotensi untuk mengelupas jika terus-menerus digunakan untuk proses pemasakan dalam suhu tinggi dan jangka waktu yang lama. Hal ini tidak sesuai dengan konsep cara produksi pangan yang baik (CPPB) untuk industri rumah tangga yang tertuang dalam peraturan kepala BPOM nomor HK.03.1.23.04.12.2206, yang menyatakan bahwa "Peralatan produksi yang kontak langsung dengan pangan sebaiknya didisain, dikonstruksi, dan diletakkan sedemikian untuk menjamin mutu dan keamanan pangan yang dihasilkan". Oleh sebab itu perbaikan terhadap peralatan masak ini merupakan salah satu program prioritas yang akan dilakukan oleh tim pengabdi. 


\section{Metode Pelaksanaan}

Metode pelaksanaan kegiatan dalam melaksanakan solusi yang ditawarkan untuk mengatasi permasalahan terdiri atas 3 tahapan, yaitu 1) Tahap inisiasi dan sosialisasi kegiatan, 2) Tahap pelaksanaan program dan 3) Tahap monitoring, evaluasi dan perbaikan berkelanjutan serta refleksi kegiatan. Adapun penjelasan tiap tahap adalah sebagai berikut:

\section{1) Tahap inisiasi dan sosialisasi kegiatan}

Dalam tahap inisiasi dan sosialisasi, dilakukan diskusi dan observasi lanjut terkait kondisi mitra. Untuk aktivitas diskusi dilakukan dua cara, selain diskusi langsung tatap muka, dilakukan juga komunikasi melalui telepon atau whatsapp. Dalam tahapan inisiasi ini didiskusikan permasalahan yang sudah diidentifikasi sebelumnya dan program yang ditawarkan untuk penyelesaiannya. Adapun urutan aktivitas adalah pembuatan peralatan pemasakan yang lebih aman (wajan terbuat dari stainless steel dan pengadukan otomatis), pembuatan mesin pengisi adonan kecap ke kemasan botol (filling machine), dan introduksi alat bantu pengangkut bahan.

\section{2) Tahap pelaksanaan program}

Setelah aktivitas/program yang akan dilakukan disepakati bersama-sama dengan mitra, selanjutnya dilakukan eksekusi. Langkah pertama adalah terkait desain peralatan pemasakan adonan. Saat ini pemasakan menggunakan wajan yang terbuat dari semen, padahal wajan ini bersentuhan langsung dengan produk. Kondisi ini tentunya berpotensi untuk menyebabkan terjadinya cemaran fisik. Dan berdasarkan konsep CPPB yang tertuang dalam Peraturan Kepala Badan Pengawas Obat dan Makanan Republik Indonesia (BPOM-RI) Nomor HK.03.1.23.04.12.2206 "bahan yang digunakan untuk peralatan yang kontak langsung dengan produk harus halus, tidak bercelah atau berlubang, tidak mengelupas, tidak berkarat dan tidak menyerap air". Peralatan yang paling cocok dengan kriteria CPPB tersebut adalah peralatan yang terbuat dari stainless steel. Oleh sebab itu dibuat wajan pemasakan dan pengaduk otomatis yang terbuat dari stainless steel.

Langkah-langkahnya adalah:

1) pengukuran,

2) pembuatan gambar alat beserta ukurannya

3) pemesanan alat ke bengkel produksi sesuai Gambar

4) pengujian alat di lab

5) pengiriman alat yang sudah selesai diuji

5) pemasangan alat/instalasi

6) pelatihan penggunaan alat

Adapun sketsa alat dapat dilihat pada Gambar 1

4) Tahap monitoring, evaluasi dan perbaikan berkelanjutan serta refleksi kegiatan

Setelah pelatihan dan serah terima alat, performa dari alat perlu tetap dipantau dan dimonitor melalui diskusi, komunikasi maupun kunjungan langsung ke UKM. Upaya-upaya perbaikan perlu terus dilakukan untuk meningkatkan performa proses dari teknologi yang diimplementasikan. Ruang-ruang perbaikan akan di identifikasi bersama mitra agar teknologi ini dapat bermanfaat bagi peningkatan tidak hanya kapasitas maupun kualitas produk yang dihasilkan oleh mitra. Evaluasi serta refleksi dilakukan untuk mengetahui tingkat penyerapan materi oleh anggota kelompok mitra dan tingkat pemahaman praktek oleh anggota kelompok mitra. Evaluasi juga dilakukan terhadap proses produksi, kapasitas, pemasaran dan perhitungan ekonomis setelah program dilakukan. Refleksi seluruh kegiatan yang selama tahap inisiasi dan tahap pelaksanaan diklat dilakukan dengan diskusi dalam tim yang diperluas dengan melibatkan Mitra dan pelaksana kegiatan. Hal ini dimaksudkan untuk mengetahui titik-titik kelemahan atau kekurangan yang terjadi selama kegiatan Diseminasi Teknologi ini berlangsung. Hasil diskusi refleksi kegiatan ini diharapkan menghasilkan rekomendasi perbaikan untuk pelaksanaan kegiatan sejenis di masa yang akan datang. 


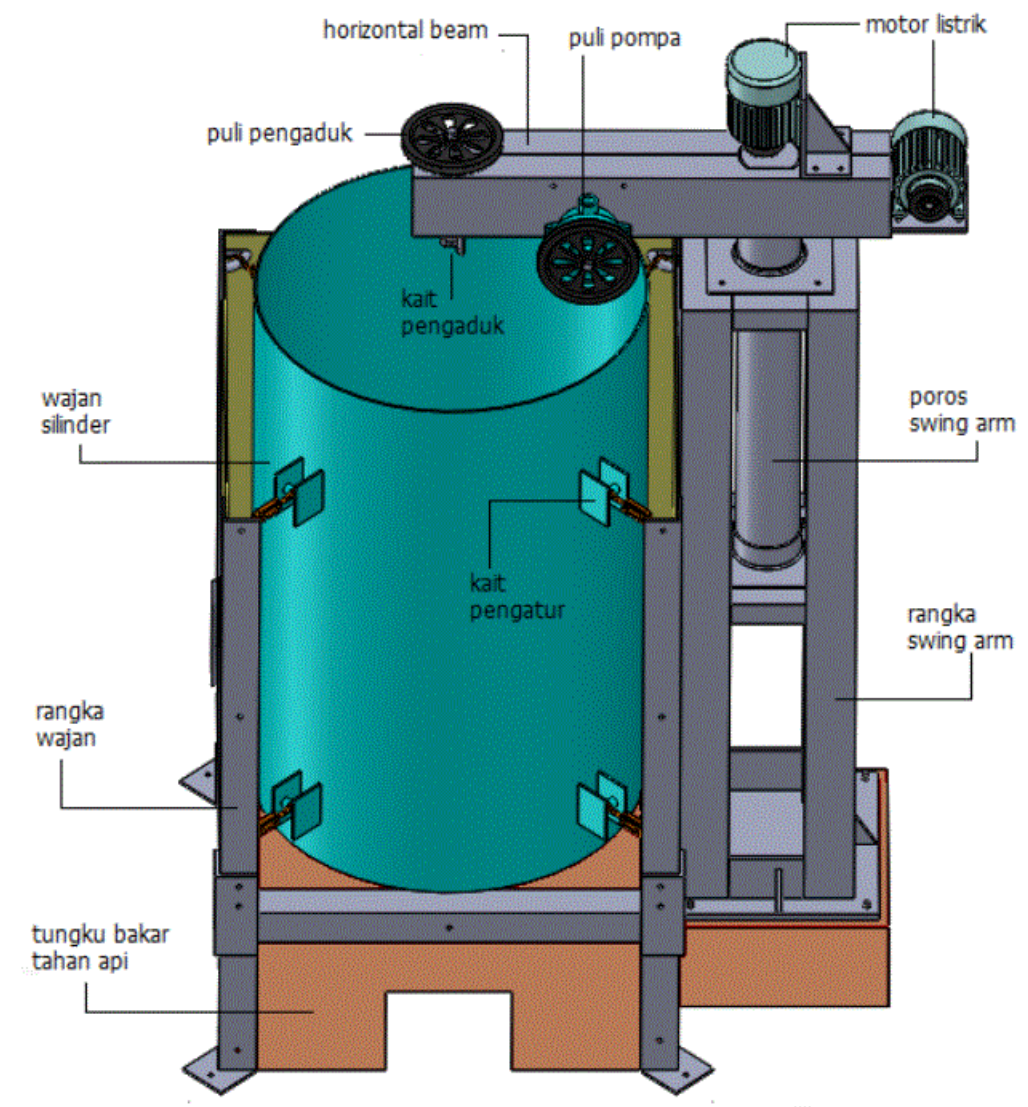

Gambar 1. Sketsa tungku dan wajan pemasakan

\section{Hasil Dan Pembahasan}

\section{1) Pra instalasi}

Aktivitas awal dari tahap ini adalah pengukuran tinggi dan diameter wajan pemasakan semen yang ada di UKM serta luas ruang produksi UKM. Selanjutnya wajan pemasakan beserta pengaduk otomatis didesain sesuai dengan kebutuhan mitra. Setelah rancangan teknologi disosialisasikan dan didiskusikan dengan mitra, pembuatan alat pun dimulai menggunakan jasa bengkel Micron Engineering yang terdapat Boyolali. Selama proses pembuatan alat, tim pelaksana pengabdian berkomunikasi dengan mitra menginformasikan perkembangan alat yang akan digunakan.

\section{2)Penerapan teknologi proses produksi dan pengemasan}

Aktivitas perbaikan dilakukan terhadap beberapa hal, yaitu: 1)material yang digunakan oleh alat yang langsung bersentuhan dengan produk kecap aman dari cemaran fisik dan kimia, 2)proses pemasakan yang lebih efisien, 3)proses pengemasan dengan waktu pengisian botol yang lebih singkat dan efisien.

\subsection{Perbaikan terhadap material/bahan untuk wajan pemasakan}

Saat ini wajan pemasakan yang dimiliki oleh UKM dinding yang bersentuhan langsung dengan adonan kecap masih terbuat dari semen (Gambar 2a). Jika digunakan terus menerus pada suhu tinggi berpotensi terjadinya pengelupasan permukaan dinding/wajan. Hal ini tentunya akan menjadi sumber pencemaran fisik yang dapat berbahaya untuk produk kecap manis. Oleh sebab itu didesain tabung berbahan stainless steel dengan ukuran spesifikasi tebal dinding $3 \mathrm{~mm}$, alas 5mm, diametar alas 780mm. Adapun berat total tabung kurang lebih $100 \mathrm{~kg}$ (Gambar 2b). Kapasitas wajan pemasakan 150 liter dengan tinggi $1.2 \mathrm{~m}$. Bahan wajan pemasakan ini kuat dan tahan terhadap suhu tinggi sehingga aman digunakan untuk memasak bahan pangan seperti kecap manis yang adonannya harus dimasak dalam waktu yang lama dengan suhu yang tinggi. Dengan kata lain, penggantian wajan pemasakan semen dengan wajan stainless 
steel ini akan mampu meningkatkan tidak hanya kualitas mutu dari produk namun juga keamanan produk pangan olahannya.

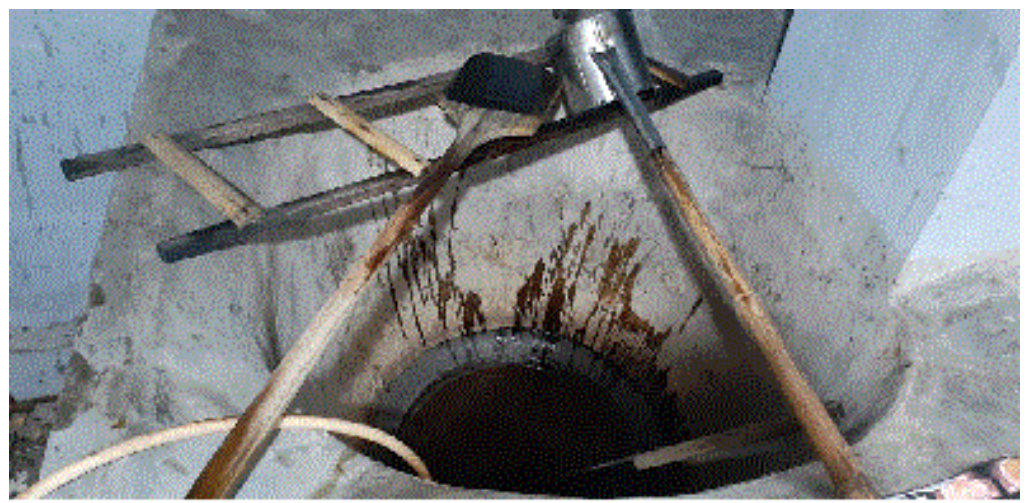

2a. wajan pemasakan terbuat dari semen

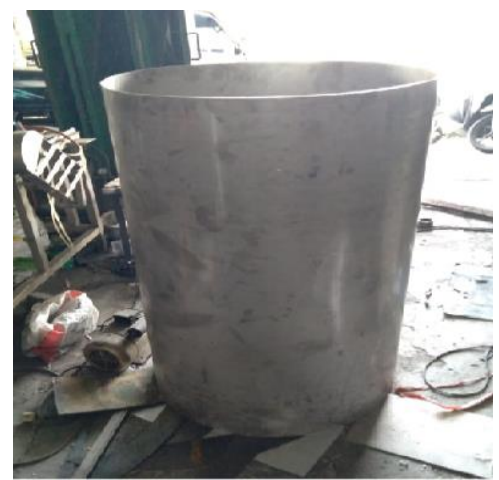

2b. wajan pemasakan stainless steel

Gambar 2. wajan pemasakan adonan kecap

\subsection{Perbaikan proses pengadukan manual menjadi pengadukan menggunakan mixer otomatis}

Saat ini proses pengadukan dilakukan secara manual (Gambar 3a) dilakukan oleh 1 sampai 2 orang (tergantung kebutuhan) dengan waktu pemasakan yang lama (sekitar 7-9 jam) tentunya proses ini tidak efisien. Perbaikan dilakukan seperti yang terlihat pada Gambar 3b, dimana pengadukan manual digantikan dengan pengadukan otomatis menggunakan mixer yang ditopang oleh rangka besi yang kokoh. Adapun mixer untuk mengaduk digerakan menggunakan motor listrik 1 phase $1 / 2 \mathrm{HP}, 10 \mathrm{Rpm}$ dengan sistem transmisi menggunakan pulley dan belt sistem. Tiang penyangga mixer berupa besi profil $\mathrm{C}$ dengan ketebalan $5 \mathrm{~mm}$ dan cover mesin besi plat esser dengan ketebalan $3 \mathrm{~mm}$. Penerapan teknologi proses menggunkan sistem pengaduk otomatis membuat proses menjadi lebih mudah dan efisien dimana operator pengadukan bisa ditugaskan untuk proses yang lain.

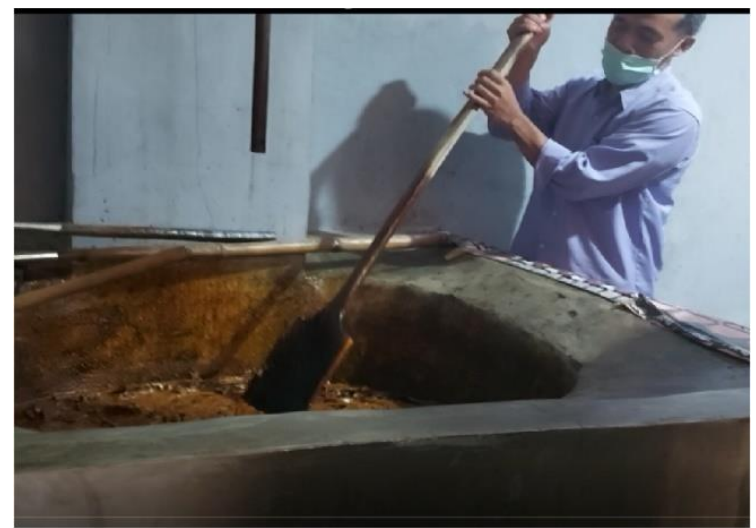

3a. Pangadukan adonan kecap secara manual

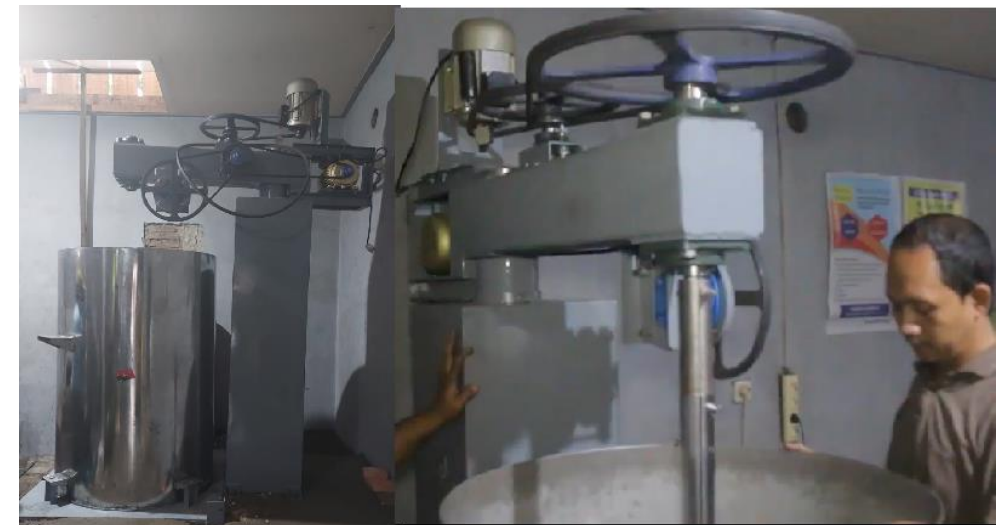

3b. Pengadukan mengunakan mesin pengaduk otomatis

Gambar 3. Mesin pengaduk adonan kecap

\subsection{Perbaikan Proses Pengemasan dengan Filling Machine Semi Otomatis}

Perbaikan selanjutnya adalah proses pengemasan. Saat ini proses pengemasan dilakukan secara manual (Gambar 4a). Adonan kecap disimpan dalam silo (tabung) penyimpanan yang mempunyai keran di bagian bawah tabung tersebut. Dengan postur tubuh jongkok, karyawan membuka dan menutup keran untuk mengalirkan kecap ke dalam botol. Proses ini membutuhkan waktu yang cukup lama (6-8 jam untuk $300 \mathrm{~kg}$ kecap) dan terkadang volume kecap yang diisikan melebihi kapasitasnya sehingga melimpah keluar menyebabkan pemborosan saat proses pengisian botol kecap. Oleh sebab itu pada proses ini didesan mesin pengisi semi otomatis dua nozzle untuk mempercepat proses pengisian botol kecap (Gambar 4b). Mesin semi otomatis dua nozzle dirancang dengan kapasitas tangki 90 liter, menggunakan sistem pneumatik dengan operasi tekanan udara 6-8 bar. Sistem kontrol menggunakan flowmeter 
Arduino dengan sumber tenaga kompressor 2 HP. Adapun bahan peralatan sudah menggunakan stainless steel sehingga aman untuk digunakan pada produk pangan.

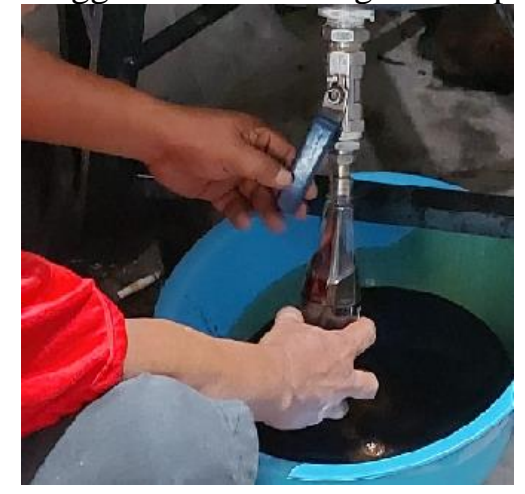

4a. Pengisian botol kecap manual satu persatu
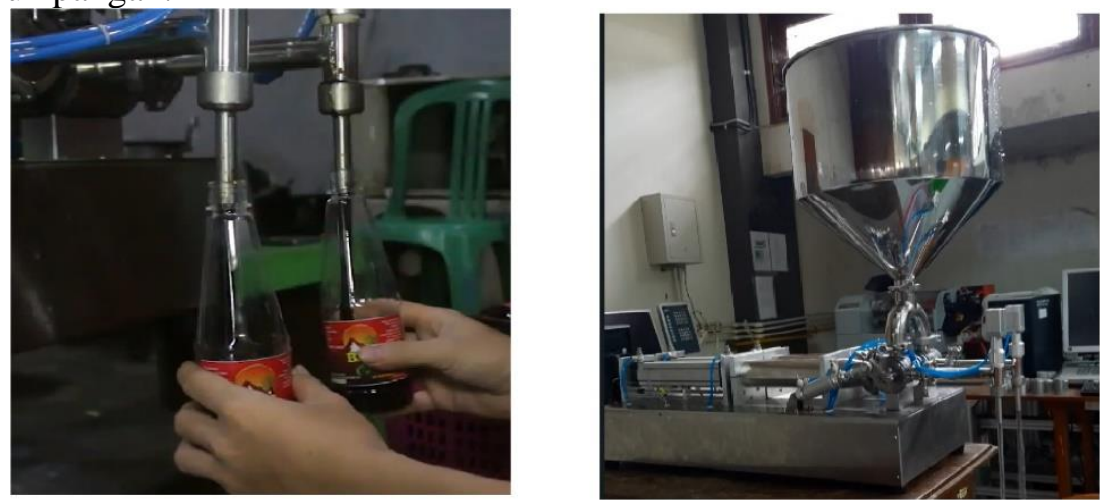

4b. Filling machine semi otomatis 2 nozzle

Gambar 4. Proses pengisian botol kecap

Penggunaan mesin pengisi otomasi ini akan signifikan meningkatkan kecepatan proses pengemasan. Dengan pengisian semi otomatis ini proses pengisian botol kecap tidak hanya akan lebih mudah dan cepat, juga akan lebih efisien karena losses yang disebabkan oleh melimpahnya kecap hingga keluar botol ketika proses pengisian akan berkurang signifikan. Metode kontrol menggunakan sensor volume yang digunakan akan memungkinkan proses pengisian lebih presisi sehingga kelebihan atau pun kekurangan volume dari standar bisa diminimalisir.

\section{3)Transfer Teknologi Proses Pengolahan Produksi Kecap}

Sebelum diserahkan ke Mitra, peralatan diuji-cobakan di laboratorium Hilirisasi, Program Studi Ilmu dan Teknologi Pangan Fakultas Pertanian UNS untuk dilakukan seting lanjutan agar tercapai performa proses produksi yang diinginkan. Setelah setingan alat dirasa sudah memenuhi harapan, selanjutnya dilakukan transfer teknologi ke mitra melalui pendampingan penggunaan alat. Pendampingan meliputi pelatihan penggunaan alat dan bagaimana cara pembersihan dan perawatannya (Gambar 5)

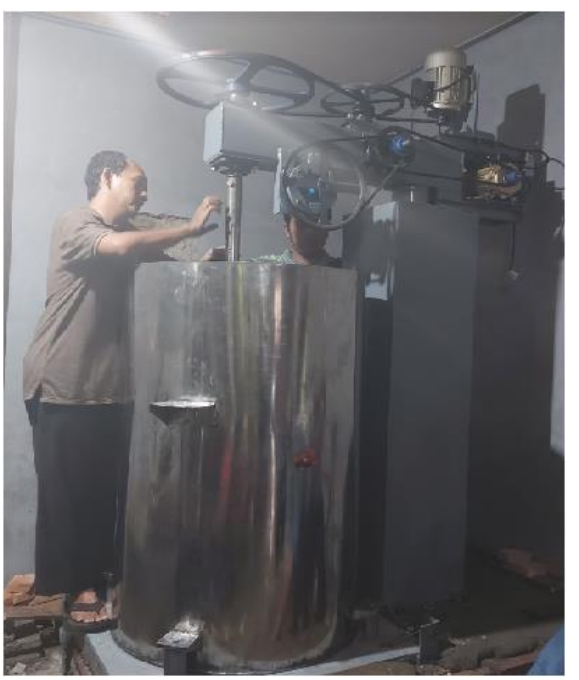

5a. Pendampingan penggunaan pengaduk otomatis
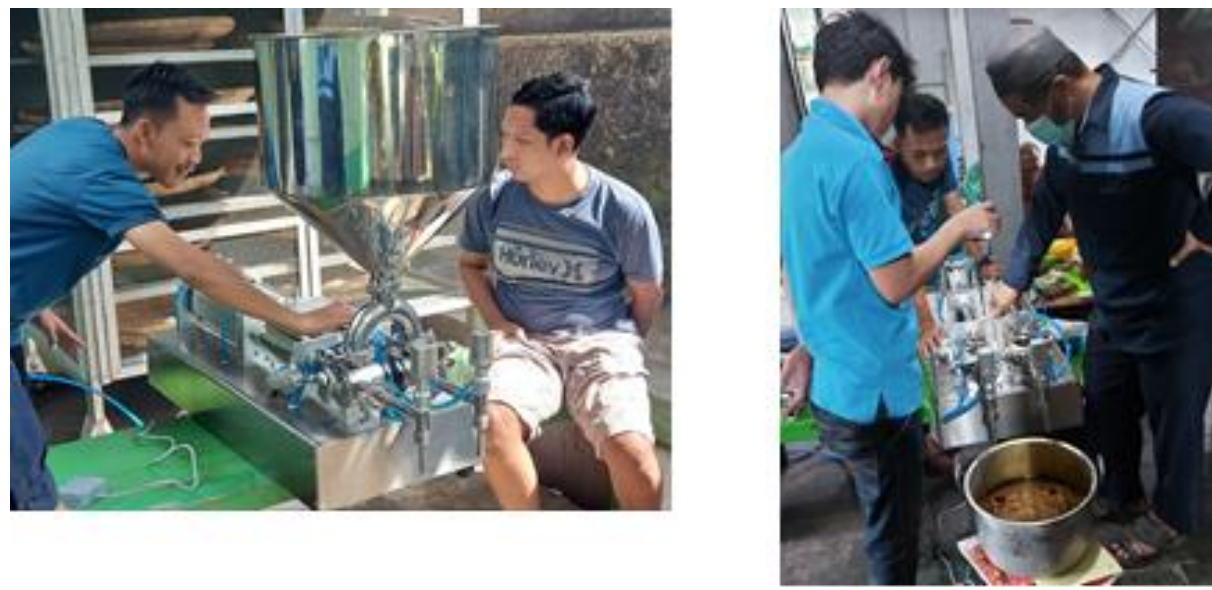

5b Pendampingan penggunaan filling machine semi otomatis dua nozzle

Gambar 5. Pendampingan penggunaan alat 
Selanjutnya dilakukan serah terima peralatan untuk proses produksi kecap manis dari tim pengabdian kepada pemilik UKM Bumi Makmur Sejahtera. Dokumentasi serah terima peralatan produksi ini dapat dilihat pada Gambar 6.
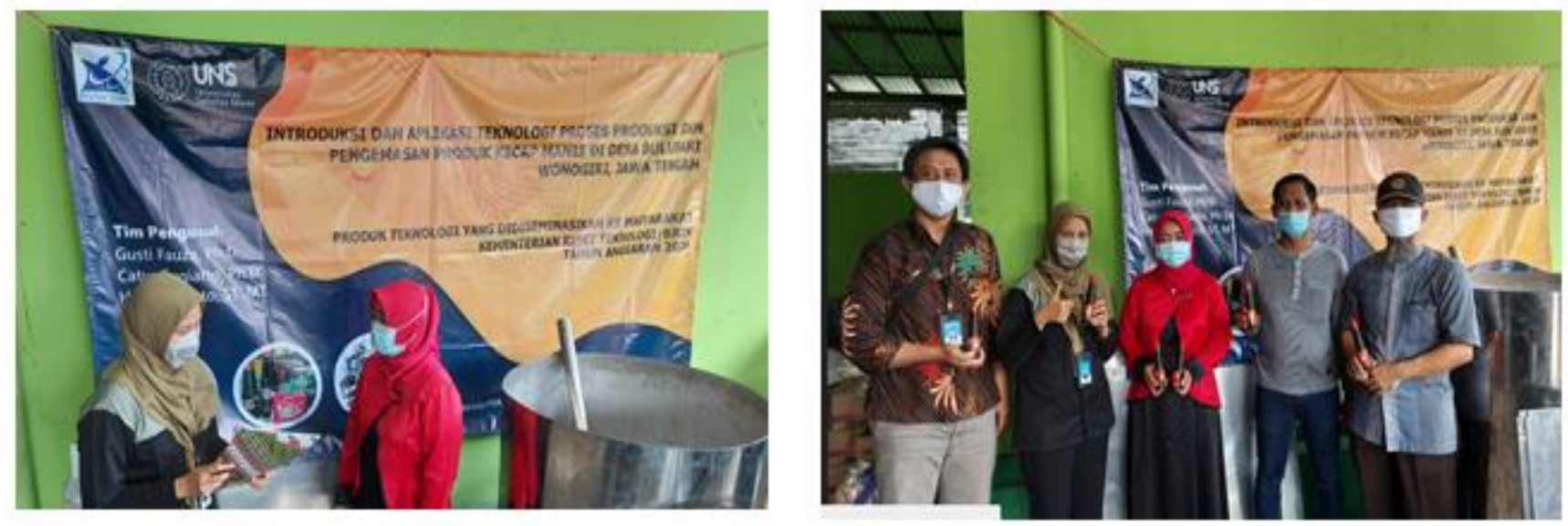

Gambar 6. Serah terima alat produksi kecap manis

Setelah serah terima alat dilakukan, komunikasi dan pendampingan UKM BMS tetap dilanjutkan untuk monitoring dan evaluasi performa dari teknologi yang telah diserahkan. Kinerja dari teknologi akan terus dipantau dan kelemahan yang masih teridentifikasi akan terus diperbaiki dan dicarikan jalan keluarnya. Selain itu juga perlu dilakukan penghitungan secara akurat tentang peningkatan kapasitas yang berhasil dicapai dengan penerapan teknologi ini. Peningkatan ini kemudian dibandingkan dengan kondisi sebelum diimplementasikannya teknologi ini. Ekspektasinya tentu saja bahwa penerapan teknologi proses ini akan meningkatkan kapasitas produksi kecap UKM BMS secara signifikan. Peningkatan kapasitas ini tentunya harus dibarengi dengan strategi distribusi dan pemasaran yang baik sehingga produk ini dapat menjangkau pasar yang lebih luas. Dengan demikian UKM akan mendapatkan keuntungan yang signifikan dari peningkatan kapasitas tersebut.

\section{Kesimpulan}

Beberapa aktivitas yang direncanakan dalam kegiatan hibah pengabdian masyarakat skema PTDM ini, sudah dilaksanakan, mulai dari desain proses teknologi, instalasi dan transfer teknologi ke UKM binaan. Meskipun demikian tentunya masih terdapat ruang untuk perbaikan proses ke depannya. Adanya komunikasi yang baik antara UKM mitra dengan tim pelaksana pengabdian merupakan faktor pendukung lancarnya kegiatan inisiasi dan sosialisasi rencana kegiatan pengabdian masyarakat ini. Untuk kegiatan selanjutnya perlu dilakukan pendampingan usaha pemasaran yang lebih intens agar produk ini lebih dikenal oleh masyarakat sehingga mempunyai jaringan distribusi pemasaran yang lebih luas.

\section{Ucapan Terima Kasih}

Penulis mengucapkan terima kasih Direktorat Riset dan Pengabdian Masyarakat, Direktorat Jenderal Deputi Bidang Penguatan Riset dan Pengembangan, Kementerian Riset, Teknologi dan Pendidikan Tinggi yang telah mendukung kegiatan ini 


\section{Daftar Pustaka}

Septiani, L. 2011. Profil sensori deskriptif kecap manis komersial Indonesia. Skripsi. Departemen Ilmu dan Teknologi Pangan, Fakultas Teknologi Pangan, Institut Pertanian Bogor. Bogor.

Maryani dan Rina. 2007. Analisis Permintaan dan Penawaran Industri Kecap di Indonesia. Skripsi. Departemen Ilmu Ekonsomi. Institut Pertanian Bogor. Bogor.

Badan Pengawas Obat dan Makanan. 2012. Peraturan Kepala Badan Pengawas Obat dan Makanan Republik Indonesia Nomor HK.03.1.23.04.12.2206 Tentang Cara Produksi Pangan yang Baik Untuk Industri Rumah Tangga. 